\title{
PENGARUH SENAM BUGAR LANJUT USIA (LANSIA) TERHADAP KUALITAS HIDUP PENDERITA HIPERTENSI
}

\author{
${ }^{1}$ Gilbert W. Setiawan \\ ${ }^{2}$ Herlina I. S . Wungouw \\ ${ }^{2}$ Damajanty H. C. Pangemanan
}

\author{
${ }^{1}$ Kandidat Skripsi Kedokteran Universitas Sam Ratulangi Manado \\ ${ }^{2}$ Bagian Fisiologi Fakultas Kedokteran Universitas Sam Ratulangi Manado \\ Email: gilbert.w.setiawan@gmail.com
}

\begin{abstract}
Hypertension is the most common illness experienced by residents in Indonesia. Hypertension is known as high blood pressure resulting from various factors. Hypertension is a serious illness and most often occur to the elderly, which greatly affect their quality of life. Focus on this research is finding the influence of elderly aerobic exercise on hypertension patients' quality of life in BPLU senja cerah paniki bawah Manado. This research is a field experiment with pre-post one group test plan. To test the significance of this study, statistic test such as t paired with level of error of $5 \%$ or 0,05 is applied. Elderly aerobic exercise is instructed to 30 elderly patients with hypertension as respondents in this study. Experiment is performed by comparing the quality of life scores, measured by filling up a short- form 36 questioners by hypertension patients before and after elderly aerobic exercise. There is a significant effect of elderly aerobic exercise towards the quality of life of hypertension patients in BPLU senja cerah paniki bawah, where the value of significance is 0,00 . This means there is an influence of quality of life before and after elderly aerobic exercise, where an increase in quality of life score emerges.
\end{abstract}

Keywords: Elderly Aerobic Exercise, Quality of life, Hypertension

\begin{abstract}
Abstrak: Hipertensi merupakan salah satu penyakit yang paling banyak dialami oleh penduduk di Indonesia. Hipertensi dikenal sebagai penyakit darah tinggi akibat dari berbagai macam faktor. Hipertensi ini merupakan penyakit serius dan paling sering terjadi terutama pada lansia yang sangat mempengaruhi kualitas hidup mereka. Fokus pada penelitian ini yaitu untuk mencari pengaruh senam bugar lansia terhadap kualitas hidup penderita hipertensi pada BPLU Senja Cerah Paniki bawah Manado. Jenis penelitian ini adalah eksperimental lapangan dengan rancangan pre-post one group test. Untuk menguji signifikan dari penelitian ini maka digunakan uji statistik berupa uji t berpasangan dengan taraf kesalahan yaitu $5 \%$ atau 0,05. Senam bugar lansia dilakukan oleh 30 responden yang menderita hipertensi. Eksperimen dilakukan dengan membandingkan skor kualitas hidup yang diukur dengan pengisian short-form 36 yang dilakukan lansia penderita hipertensi sebelum dan sesudah senam bugar lansia. Terdapat pengaruh yang signifikan antara senam bugar lansia terhadap kualitas hidup pasien penderita hipertensi di BPLU Senja Cerah Paniki Bawah dimana nilai signifikannya 0,000. Artinya ada pengaruh kualitas hidup sebelum dan sesudah senam buagr lansia, dimana terjadi peningkatan skor kualitas hidup.
\end{abstract}

Kata Kunci: senam bugar lansia, kualitas hidup, hipertensi

Hipertensi merupakan salah satu masalah kesehatan masyarakat yang utama di negara-negara negara-negara maju serta di beberapa berkembang. ${ }^{1} \quad$ Indonesia 
sebagai salah satu negara berkembang juga menghadapi masalah ini. $^{2}$ Hipertensi merupakan penyakit yang sering disebut sebagai silent killer, jika tidak terkontrol dapat memicu timbulnya penyakit degeneratif, seperti gagal jantung kongestif, gagal ginjal, dan berbagai penyakit vaskuler. $^{1,2}$

Hipertensi merupakan salah satu penyakit yang mempunyai hubungan yang sangat erat dengan lansia., ${ }^{2,3}$ Hal ni terjadi akibat perubahan fisiologis yang terjadi seperti penurunan respons imunitas tubuh, katup jantung menebal dan menjadi kaku, penurunan kemampuan kontraktilitas jantung, berkurangnya elastisitas pembuluh darah, serta kurangnya efektifitas pembuluh darah perifer untuk oksigenasi. ${ }^{4,5}$ Perubahan-perubahan inilah yang menyebabkan peningkatan resistensi vaskuler sehingga lansia cenderung lebih rentan mengalami hipertensi. ${ }^{3,4}$

Penanganan hipertensi dapat dilakukan dengan memperbaiki pola hidup dan dengan terapi farmakologis. ${ }^{3}$ Salah satu cara memperbaiki pola hidup adalah dengan melakukan aktivitas fisik yang teratur. Aktivitas fisik terhadap penderita hipertensi bertujuan untuk menurunkan tekanan darah melalui beberapa mekanisme seperti perubahan neurohumoral, adaptasi struktur pembuluh darah, serta penurunan katekolamin dan tahanan perifer total. ${ }^{3,6}$

Aktivitas fisik yang dilakukan secara teratur terbukti dapat meningkatkan kualitas hidup secara fisik dan mental seseorang. Peningkatan kualitas hidup secara fisik antara lain peningkatan metabolisme glukosa, penguatan tulang dan otot, serta mengurangi kadar koleterol dalam darah. ${ }^{6,7}$ Peningkatan kualitas hidup secara mental yang diperoleh melalui aktivitas fisik ialah mengurangi stres, meningkatkan rasa antusias dan rasa percaya diri, serta mengurangi kecemasan dan depresi seseorang terkait dengan penyakit yang dialaminya. ${ }^{8}$ Senam bugar lansia merupakan salah satu aktivitas fisik yang dapat dilakukan untuk mengurangi peningkatan tekanan darah yang terjadi pada penderita hipertensi. ${ }^{3}$
Short Form 36 atau SF-36 merupakan kuesioner berisi 36 item yang yang didesain sebagai alat ukur kualitas hidup secara generik yang digunakan untuk survei populasi dan studi evaluasi kebijakan kesehatan. $^{9}$ Oleh karena permasalahan diatas, peneliti tertarik untuk mengetahui pengaruh senam bugar lansia terhadap kualitas hidup penderita hipertensi. Keuntungan memakai alat ukur generik Short Form-36 adalah dapat digunakan pada berbagai kondisi penyakit secara luas, dapat untuk membandingkan status kesehatan pada kondisi yang berbeda (penyakit yang berbeda), dapat membandingkan penderita dengan populasi normal., ${ }^{9,10}$

\section{METODE PENELITIAN}

Jenis penelitian yang dilakukan bersifat eksperimental lapangan dengan rancangan penelitian one group pre-post test. Penelitian ini dilaksanakan antara bulan November 2012 sampai bulan Desember 2012. Tempat penelitian di Balai Penyantunan Lanjut Usia (BPLU) Senja Cerah. Populasi penelitian ini adalah semua pasien lanjut usia (lansia) dengan riwayat penyakit hipertensi di BPLU Senja Cerah. Sampel penelitian diambil dari sebagian populasi yang sesuai dengan kriteria inklusi, seperti tekanan darah sistolik $\geq 130$ mmHg dan atau tekanan darah diastoli $90 \mathrm{mmHg}$, pasien lanjut usia dengan umur $\geq 60$ tahun, tidak ada keluhan untuk mengikuti senam lanjut usia, bersedia menjadi subjek dan menandatangani informed consent.

Definisi operasional lanjut usia (lansia) adalah seseorang yang berumur $\geq 60$ tahun ke atas. Pengelompokkan usia menggunakan pembagian menurut $\mathrm{WHO}$, dengan usia 45-60 tahun (middle age), usia 60-75 tahun (elderly), usia 75-90 tahun (old), usia diatas 90 tahun (very old). Penderita hipertensi adalah orang yang telah didiagnosis oleh dokter dengan hipertensi dan memiliki tekanan darah sistolik $\geq 130 \mathrm{mmHg}$ dan atau tekanan darah diastoli $\underline{x} 90 \mathrm{mmHg}$. Pengisian 
kuesioner short form-36 dilakukan sebelum dan sesudah senam bugar lansia. Hasil penelitian diuji dengan paired sample t-test yang digunakan untuk menentukan pengaruh senam bugar lansia terhadap kualitas hidup yang diukur dengan skor kuesioner short form-36.

\section{HASIL PENELITIAN}

Sampel diambil dari sebagian populasi yang telah memenuhi kriteria inklusi dan diperoleh sebanyak 33 subjek. Tiga responden dieksklusi, dikarenakan responden tersebut tidak mengikuti seluruh prosedur penelitian, sehingga sampel penelitian menjadi 30 responden. Berikut ini akan diuraikan hasil penelitian dalam bentuk tabulasi dan penjelasan.

\section{Distribusi responden berdasarkan umur}

Pengelompokkan usia ini menggunakan pembagian menurut WHO. Subjek yang termasuk kelompok elderly sebanyak 17 orang (56,7 \%) dengan jarak umur 60 sampai 74 tahun, sedangkan kelompok old sebanyak 13 orang (43,3\%) dengan jarak umur 75 sampai 90 tahun.

Tabel 1. Distribusi responden berdasarkan umur

\begin{tabular}{ccc}
\hline & Frekuensi & $\begin{array}{c}\text { Persentasi } \\
(\mathbf{\%})\end{array}$ \\
\hline Elderly & 17 & 56,7 \\
Old & 13 & 43,3 \\
\hline
\end{tabular}

\section{Distribusi responden berdasarkan jenis kelamin}

Subjek dengan jenis kelamin laki-laki sebanyak 10 orang (33,3 \%) dengan rerata kadar asam urat senilai 10,40 mg/dl. Subjek dengan jenis kelamin perempuan berjumlah lebih banyak, yakni 20 orang (66,7 \%).
Tabel 2. Distribusi responden berdasarkan jenis kelamin

\begin{tabular}{lcc}
\hline & Frekuensi & $\begin{array}{c}\text { Persentase } \\
\text { (\%) }\end{array}$ \\
\hline Laki-laki & 10 & 33,3 \\
Perempuan & 20 & 66,7 \\
\hline
\end{tabular}

\section{Distribusi kadar asam urat subjek} berdasarkan klasifikasi tekanan darah

Diperoleh subjek dengan hipertensi stage 2 menduduki peringkat pertama dengan 43,3 \% (13 orang). Hipertensi stage 1 diperingkat kedua dengan 36,7 \% (11 orang) dan lansia yang merupakan prehipertensi sebanyak 6 orang (20\%).

Tabel 3. Distribusi subjek berdasarkan klasifikasi tekanan darah

\begin{tabular}{lcc}
\hline & Frekuensi & $\begin{array}{c}\text { Persentase } \\
(\mathbf{\%})\end{array}$ \\
\hline Prehipertensi & & \\
Hipertensi & 6 & 20 \\
stage 1 & 11 & 36,7 \\
Hipertensi & 13 & 43,3 \\
stage 2 & & \\
\hline
\end{tabular}

\section{Rerata skor kuesioner SF-36 sebelum dan sesudah senam bugar lansia}

Berdasarkan hasil olah data (gambar 1), didapatkan nilai rata-rata skor kuesioner SF-36 sebelum senam sebesar 66,38 \pm 11,97, sedangkan nilai rata-rata skor kuesioner SF-36 setelah senam selama 3 minggu sebesar 75,65 8,14.

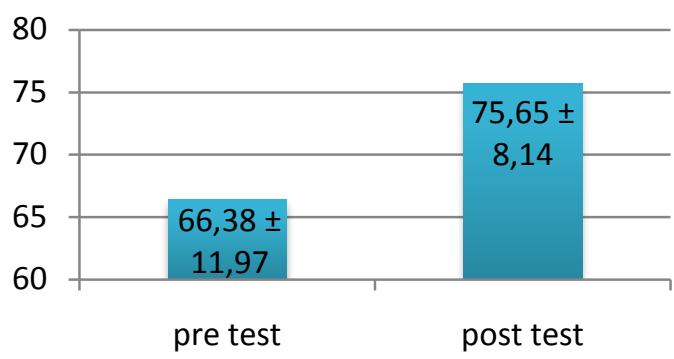

Gambar 1. Perbandingan skor kuesioner SF36 subjek penelitian 


\section{DISKUSI}

Pengklasifikasian tekanan darah dalam penelitian ini berdasarkan klasifikasi tekanan darah menurut The Seventh Report of the Joint National Committee on Prevention, Detection, Evaluation, and Treatment of High Blood Pressure (JNC 7) untuk pasien dewasa (umur $\geq 18$ tahun). Diperoleh hasil bahwa semua subjek memiliki tekanan darah tinggi, dan hipertensi stage 2 menduduki peringkat pertama dengan 43,3\% (13 orang) seperti yang terlihat pada Tabel 3.

Banyaknya responden dengan hipertensi stage 2 mungkin dikarenakan salah satu dari faktor resiko hipertensi stage 2 sesuai dengan teori dimana pertambahan umur diikuti dengan perubahan anatomi dan fisiologi seperti penebalan katup-katup jantung, penurunan elastisitas dinding aorta, hal inilah yang menjadi penyebab peningkatan faktor resiko hipertensi pada lansia. ${ }^{4}$

Olahraga yang baik dilakukan oleh lansia antara lain berjalan kaki, senam lansia, senam jantung sehat, dan yoga. Senam bugar lansia merupakan salah satu olahraga yang sangat baik karena dapat meningkatkan fleksibilitas sendi, kekuatan tulang dan otot dan mengoptimalkan kerja jantung, serta mengurangi tingkat depresi dan kecemasan pada lansia sehingga dapat meningkatakan kualitas hidup lansia dari segi kesehatan fisik dan mental. ${ }^{11}$

Berdasarkan hasil penelitian mengenai pengaruh senam bugar lansia terhadap kualitas hidup penderita hipertensi yang diukur dengan kuesioner SF-36, didapatkan bahwa nilai rata-rata skor kuesioner sebelum diberi perlakuan senam sebesar $66,38 \pm 11,97$ dan setelah diberi perlakuan senam selama 3 minggu menurun menjadi 75,65 $\pm 8,14$ (Gambar 1), hasil ini menunjukan peningkatan yang sangat baik terhadap kualitas hidup yang sangat baik pada penderita hipertensi. hal ini sesuai dengan penelitian yang dilakukan oleh Herlina dimana pemberian aktivitas fisik berupa latihan aerobik pada lansia dapat meningkatkan kualitas hidup yang diukur dengan Mac New Heart Disease Health Related QoL disertai dengan peningkatan kekuatan dan stamina serta mengurangi kecemasan dan depresi yang dialami oleh kaum lansia. ${ }^{12}$ Hasil ini juga sesuai dengan penelitian yang dilakukan oleh Acree dan Longfors dimana mereka melakukan pengukuran kualitas hidup dengan SF-36 pada kelompok yang melakukan aktivitas tinggi dan kelompok yang melakukan aktivitas rendah, hasilnya kelompok yang melakukan aktivitas tinggi memliki skor kuesioner lebih tinggi dibandingkan dengan kelompok yang melakukan aktivitas rendah. $^{13}$

Hasil penelitian ini menunjukkan bahwa terjadi peningkatan skor kualitas hidup rata-rata sebesar 9,27. Nilai signifikasi (p) dari hasil uji statistik yaitu 0,00 lebih kecil dari nilai alpha $(\alpha=0,05)$, sehingga menunjukkan adanya pengaruh yang signifikan senam bugar lansia terhadap kualitas hidup penderita hipertensi.

\section{SIMPULAN DAN SARAN}

Berdasarkan pembahasan di atas, dapat diambil kesimpulan bahwa ada pengaruh signifikan antara senam bugar lansia terhadap kualitas hidup penderita hipertensi $(p<0,05)$. Senam bugar lansia yang telah dilakukan tetap dipertahankan untuk menjaga kebugaran dan mencegah penyakit hipertensi dan meningkatakan kualitas hidup baik secara fisik maupun mental. Perlu juga penelitian lebih lanjut dengan jumlah sampel yang lebih banyak dan bervariasi.

\section{UCAPAN TERIMA KASIH}

Ucapan terima kasih disampaikan pada Dr. H. I. S. Wungouw, MsAppSc, MMedEd, AIFM, AIFO, Dr. D. H. C. Pangemanan, M.Kes, AIFM, AIFO, dan pada semua pihak yang baik secara langsung maupun tidak langsung telah menumbuhkan ide tau gagasan dalam pemikiran penulis sehingga dapat menyelesaikan artikel ini. 


\section{DAFTAR PUSTAKA}

1. Whelton PK. Epidemiology and the prevention of hypertension. J Clin Hypertens. 2004;6(11):636-42.

2. Rahajeng E, Tuminah S. Prevalensi hipertensi dan determinannya di Indonesia. Maj Kedokt Indon. 2009;59(12):580-587.

3. U.S. Department of Health and Human Services. The Seventh Report of the Joint National Committee on Prevention, Detection, Evaluation, and Treatment of High Blood Pressure. National Institute of Health; 2004.

4. Darmojo,R.B.Martono,H. Geriatri: Ilmu Kesehatan Usia Lanjut (Edisi ke-4). Jakarta: Fakultas Kedokteran Universitas Indonesia, 2011; p.348-51.

5. Fatimah. Respons Imunitas Yang Rendah Pada Tubuh Manusia Usia Lanjut. Jurnal Makara, Kesehatan. 2006;10(1):47-53.

6. American College Of Sports Medicine. Position stand: Exercise and Hypertension. Med. Sci. Sports Exerc. 2004;30:533-53.

7. Haskell WL, Lee IM, Pate RR, Powell KE, Blair SN, Franklin BA, et al. Physical activity and public health: updated recommendation for adults from the American college of sports medicine and the American heart association. American college of sports medicine and the American heart association. 2007;1423-34.

8. Taylor CB, Sallis JF, Needle R. The relation of physical activity and exercise to mental health. Public health reports. 1985; 100(2):195-202.

9. Brazier JE, Harper E, Jones NM, Cathain AO, Thomas KJ, Usherwood $\mathrm{T}$, et al. Validating the SF-36 health survey quesitionnaire: new outcome measure for primary care. BMJ. 1992;305:160-4.

10. Rutta DA, Abdalla MI, Garrat AM, Coutts A, Russel IT. SF 36 health survey questionnaire: I. reliability in two patients based studies. Quality in health care. 1994;3:180-5.

11. Sukartini T, Nursalam. Manfaat senam tera terhadap kebugaran lansia. J. Penelit. Med. Eksakta. 2009;8:2.

12. Wungouw H. Physical exercise and Quality of life in patients with Cardiac disease. Jurnal kedokteran YARSI. 2006;14(3):2307.

13. Acree L, Longfors J, Physical activity is related to quality of life in elder adults. Biomed central. 2006. 